\title{
David Oliver: Time for a truly independent NHS statistics authority
}

\author{
David Oliver consultant in geriatrics and acute general medicine
}

Berkshire

In the current febrile environment around health policy, I propose that we need a statutory Independent Office for Health and Care Statistics.

I have no problem when politicians, government department public relations teams, media commentators, lobbyists with vested interests, or privately funded, partisan political think tanks with ideological agendas take positions; whether on the funding of health and care systems, current and future workforce, or historical or international comparisons of performance.

But I do have a problem with them partially selecting or wilfully misrepresenting data-until the soundbites and assertions, cobbled together from factoids, enter the public consciousness as received gospel.

People on all sides pump out inaccurate or partial information to justify their cause. For instance, the government said last October that the NHS would receive an additional £10bn by 2020, but the King's Fund showed that the additional funding is only around $£ 4.5 \mathrm{bn} .{ }^{1}$ Jeremy Hunt, the health secretary, also erroneously claimed that the NHS had received the sixth biggest funding increase in its history. ${ }^{2}$ Similar examples abound.

Soundbites and assertions, cobbled together from factoids, enter the public consciousness as received gospel

In 2010 the United Kingdom established the Office for Budget Responsibility $^{3}$ : a statutory body, independent of political interference, to provide rigorous, neutral, expert economic forecasts and information. More recently, the Labour Party called for a similar body for health finances (though not for other types of data). ${ }^{4}$

The Office for National Statistics ${ }^{5}$ provides a range of highly respected national data relevant to many areas of public policy, including healthcare. The National Audit Office, ${ }^{6}$ which also has a statutory politically independent role, produces hard hitting and well evidenced reports on key aspects of health and social care service delivery-most recently on delayed transfers of care and on health and social care integration. ${ }^{78}$ This year the National Institute of Economic and Social Research produced pre-election briefings on the real scale of the NHS funding crisis. ${ }^{9}$ The credibility of such bodies derives from their political neutrality, genuine expertise, institutional memory, transparency, and freedom from spin. Similar considerations apply to the three high profile health policy think tanks: the Nuffield Trust, ${ }^{10}$ the King's Fund, ${ }^{11}$ and the Health Foundation, ${ }^{12}$ which speak truth to power in well evidenced critiques.

We can turn to these organisations for credible, unbiased information. But even they get occasional accusations of ideological bias or closeness to government. A new, single, independent NHS statistics authority would allow all sides discussing current and future healthcare performance, provision, and funding to agree about the data under discussion and would provide an instant fact check. If we could agree that the data were indeed the data, then we could move on to the legitimate, big questions of health policy debate rather than using partial or specious numbers to kill them.

Competing interests: See www.bmj.com/about-bmj/freelancecontributors/david-oliver.

Provenance and peer review: Commissioned; not externally peer reviewed.

Follow David on Twitter: @mancunianmedic

Ham C, King's Fund. Assessing the credibility of election manifesto promises on health and social care. 24 Apr 2017. https://www.kingsfund.org.uk/blog/2017/04/electionmanifesto-promises-health-social-care.

2 Appleby J, King's Fund. How does this year's NHS budget compare historically? 11 May 2016. https://www.kingsfund.org.uk/blog/2016/05/how-does-this-years-nhs-budgetcompare-historically.

3 Office for Budget Responsibility. http://budgetresponsibility.org.uk/.

4 Campbell D, Asthana A. Labour calls for OBR-style watchdog to assess NHS finances. Guardian 27 Dec 2016. https://www.theguardian.com/politics/2016/dec/27/labour-callsGuardian 27 Dec 2016. https://www.theguardian.

Office for National Statistics. https://www.ons.gov.uk/.

6 National Audit Office. https://www.nao.org.uk/.

7 National Audit Office. Discharging older patients from hospital. May 2016. https://www. nao.org.uk/report/discharging-older-patients-from-hospital/.

8 National Audit Office. Health and social care integration. Feb 2016. https://www.nao.org. uk/report/health-and-social-care-integration/.

9 National Institute of Economic and Social Research. Is NHS funding in crisis? NIESR general election 2017-briefing no 5. 30 May 2017. www.niesr.ac.uk/sites/default/files/ publications/NIESR\%20Briefing\%20Paper\%20No5\%20-\%20ls\%20NHS\%20Funding\% 201 \% 20 Crisis.pdf.

10 Nuffield Trust. https://www.nuffieldtrust.org.uk/. 
11 King's Fund. https://www.kingsfund.org.uk/

12 Health Foundation. www.health.org.uk.
Published by the BMJ Publishing Group Limited. For permission to use (where not already granted under a licence) please go to http://group.bmj.com/group/rights-licensing/ permissions 